\title{
Effect of Maize Plants Distribution and Nitrogen Fertilization Levels in Peanut-Maize Intercrop
}

\author{
A.S. Shams, A.S. El-Debaby *, A. Roshdy ${ }^{*}$ and A.S. Kamel \\ Crop Intensification Research Department, FCRI, ARC, Giza \\ and *Agronomy Department, Faculty of Agriculture, \\ Moshtohor, Benha Univ., Benha, Egypt.
}

\begin{abstract}
7 WO FIELD trials were carried out at Ismailia Agricultural Research Station, Agricultural Research Center in 2003 and 2004 summer seasons in sandy soil, to study the interaction effect of intercropping patterns, peanut: maize $(2: 1),(1: 1)$ and (1:2); orientation of maize plants (the shade crop): spacing maize plants at $35 \mathrm{~cm}$ apart and leaving one plant/hill, spacing maize plants at $70 \mathrm{~cm}$ apart and leaving two plants/hill and nitrogen fertilizer levels 60,90 and $120 \mathrm{~kg}$ $\mathrm{N} / \mathrm{fed}$. Pure stand plots of both peanut and maize were included in each replicate for land equivalent ratio (LER) and net return essays. Treatments were assigned randomly in factorial Randomized Complete Block Design (RCBD) and replicated for four times. Peanut cv. Giza 5 (Main crop - understory crop) was planted on $23^{\text {rd }}$ and $25^{\text {th }}$ May in 2003 and 2004 seasons, respectively, whereas maize cv. single cross 10 (Shade crop - overstory crop) was planted on $13^{\text {th }}$ and $15^{\text {th }}$ June in 2003 and 2004 seasons, respectively. Peanut was planted with intra spacing of $10 \mathrm{~cm}$ apart on one side of the ridges with population of 70000 plants/fed when intercropped or in pure stand.
\end{abstract}

Results revealed that intercropping peanut grown $50 \%$ of full maize stand $\left(2.4\right.$ plants $\left./ \mathrm{m}^{2}\right)$ in $(1: 1)$ pattern under orientated at $70 \mathrm{~cm}$ apart leaving two plants/hill and adding $120 \mathrm{~kg} \mathrm{~N} /$ fed for the two components resulted in maximum net return of 1851.71 and 2214.95 L.E. with maximum LER of 1.44 and 1.41 in first and second season, respectively.

Keywords: Intercropping, Peanut, Maize, Intercropping patterns, Nitrogen fertilizer.

In sandy soil of Egypt, where peanut is considered the main summer crop, intercropping is popular now among the small holders in Egypt. A reason for this popularity is built on profit and resource maximization and efficient water utilization. However, to determine the processes which lead to the advantages and to maximize benefits, it is necessary to evaluate best intercropping patterns. Since, peanut is the main understory crop, preferably, occupying the whole cultivated area of sandy soil, the geometrical distribution of maize (The shade crop) is expected to play an important role to maximize production and gross income of the intercrop per unit area of land. 
Intercropping peanut with maize attracted the attention of some investigators as Mandimba et al. (1993), Liphadzi et al. (1997), Abd El-Motaleb \& Yousef (1998) and Metwally et al. (2005).

Studies on maize densities whether maize spacing or number of maize plant/hill which remain after thinning and the fertilization rate and the intercropping pattern seemed to be of prime importance in optimizing the association. Hussein, et al. (2002), Hussein et al. (2005), Sherif, et al. (2005) and Abd El-Motaleb \& Yousef (1998) found that peanut responded positively to increasing $\mathrm{N}$ level from 40 to $80 \mathrm{~kg} \mathrm{~N} /$ fed.

Hussein et al. (2005) recorded that highest yield of peanut was obtained when peanut was intercropped with maize on ridges $(60 \mathrm{~cm}$ width) and received $102.5 \mathrm{~kg} \mathrm{~N} /$ fed.

Several years have been devoted on elaborative research in order to figure out the most productive intercropping pattern. However, the appropriate decision and the correct choice of the most biologically efficient pattern of peanut-maize association have not been reached. Therefore, the objective of the present study is to investigate the interrelationship of peanut-maize intercropping patterns, the geometric and plant density of maize (the shade crop) in sandy soil compared with sole planting of the two crops and the effect of various levels of nitrogen fertilization.

\section{Materials and Methods}

Two field trials were carried out at Ismaillia Agricultural Research Station, Agricultural Research Center (2003 and 2004 seasons) in the sandy soil, to study the interaction effect of intercropping patterns, orientation of maize plants and nitrogen fertilization levels on yield and yield component traits of peanut and maize in the intercrop and assay land equivalent ratio (LER) and net return between both components in the intercrop. Eighteen treatments were the combinations of: 1 - Three intercropping patterns (Peanut was grown on all ridges and maize was grown on the other side of: a- The third ridge in (2: 1) pattern $100 \%$ peanut and $33 \%$ maize, b- The second ridge in (1: 1) pattern - $100 \%$ peanut and 50\% maize and c- The second and third ridges in (1: 2) pattern $100 \%$ peanut and $67 \%$ maize), 2- Two orientation of maize plants (Maize thinned to: a- One plant/hill and $35 \mathrm{~cm}$ apart. and b- Two plants/hill and $70 \mathrm{~cm}$ apart.) and 3- Three nitrogen fertilization levels (60, 90 and $120 \mathrm{~kg} \mathrm{~N} / \mathrm{fed}$ ). Pure stand plots of both peanut and maize were included in each replicate for land equivalent ratio (LER) and net return essays. Both treatments were not involved in the statistical analysis.

Plot area was $12.6 \mathrm{~m}^{2}$ and consisted of 6 ridges, each was $3.5 \mathrm{~m}$ in length and $0.6 \mathrm{~m}$ in width.

Egypt. J. Agron. 34, No. 1 (2012) 
The soil was sandy textured $(67.98 \%$ coarse sand, $24.56 \%$ fine sand, $3.13 \%$ silt and $4.33 \%$ clay), with $7.8 \mathrm{pH}, 0.47 \%$ organic matter content, $18.21 \mathrm{ppm}$ available N, $2.19 \mathrm{ppm}$ available $\mathrm{P}$ and $73.98 \mathrm{ppm}$ available K. (Average of the two seasons).

Peanut cv. Giza 5 (Main crop - understory crop) was seeded on $23^{\text {rd }}$ and $25^{\text {th }}$ May in 2003 and 2004 seasons, respectively, whereas maize cv. single cross 10 (Shade crop - overstory crop) was seeded on $13^{\text {th }}$ and $15^{\text {th }}$ June in 2003 and 2004 seasons, respectively. Two sprinkler irrigations were carried out every week. Peanut was seeded with intra spacing of $10 \mathrm{~cm}$ apart on one side of the ridges with population of (70000 plants/fed) when intercropped or in pure stand. Whereas, maize was planted according to the treatment imposed. Phosphatic fertilization was added during land preparation at the rate of $30 \mathrm{~kg}_{2} \mathrm{O}_{5} / \mathrm{fed}$ in the form of Calcium Super Phosphate $\left(15.5 \% \mathrm{P}_{2} \mathrm{O}_{5}\right)$. Nitrogen fertilization was applied at the rates of 60,90 and $120 \mathrm{~kg} \mathrm{~N} / \mathrm{fed}$ in the form of Ammonium Sulphate $(20.5 \% \mathrm{~N}) / \mathrm{fed}$. Application of nitrogen fertilizer was in three equal split up doses. The first dose was after four weeks from peanut planting date, the second dose was after three weeks from first dose and the third dose was after three weeks from the second dose. Potassic fertilization was applied at the rate of $24 \mathrm{~kg} \mathrm{~K} 2 \mathrm{O} / \mathrm{fed}$ in the form of Potassium Sulphate $\left(48 \% \mathrm{~K}_{2} \mathrm{O}\right)$ with the second dose of nitrogen fertilization. Harvesting of peanut was after 120 days from seeding peanut and maize was after 120 days from seeding maize in both seasons.

\section{Data Recorded}

At harvest (after 120 days from planting) a sample of ten plants were taken at random, from the pure stand from intercropped plots of peanut and maize. The following data were recorded:

\section{Peanut}

- Number of pods/plant, weight of pods/plant (gm), weight of seeds/plant (gm), 100-seed weight (gm).

- Pod and straw yields/fed (ton) were determined on the plot basis.

\section{Maize}

- Ear length $(\mathrm{cm})$, ear diameter $(\mathrm{cm})$, ear weight $(\mathrm{gm})$, weight of kernels/ear (gm), 100-grain weight (gm).

- Grain and straw yields/fed (ton) were determined on the plot basis.

\section{Land equivalent ratio (LER)}

LER determined as the sum of the fractions of the yield of the intercrops relative to their sole crop yields according to the following formula (Willey, 1979): $\mathrm{LER}=\left[\left(\mathrm{Y}_{\mathrm{ab}} / \mathrm{Y}_{\mathrm{aa}}\right)+\left(\mathrm{Y}_{\mathrm{ba}} / \mathrm{Y}_{\mathrm{bb}}\right)\right]$

where: $\bullet Y_{a a}$ and $Y_{b b}$ means: Pure stand yield of crop (a) and (b), respectively.

- $\mathrm{Y}_{\mathrm{ab}}$ and $\mathrm{Y}_{\mathrm{ba}}$ means: Intercrop yield of crop (a) and (b), respectively. 
Net return fed ${ }^{-1}$

Net return was calculated for each treatment in the Egyptian pounds LE fed ${ }^{-1}$ for peanut and maize in intercropping or in pure stand according to Economic Affairs Sector EAS (2004 and 2005) for both years.

Statistical analysis

Data were analyzed using ANOVA in factorial Randomized Complete Block Design (RCBD) with four replications. MSTAT-C (1988) was used for statistical computations.

\section{Results and Discussion}

Peanut.

Effect of intercropping patterns

Results in Table 1 indicate clearly that highest values of yield and its component traits were evident when peanut was grown under $33 \%$ of full density of maize $\left(1.6\right.$ plant $\left./ \mathrm{m}^{2}\right)$ in $(2: 1)$ pattern. These results were true in both seasons. Several investigators support these results such as Mandimba et al. (1993), Liphadzi et al. (1997), Abd El-Motaleb \& Yousef (1998) and Metwally et al. (2005).

TABLE 1. Effect of intercropping patterns on yield and yield component traits of peanut in 2003 and 2004 seasons.

\begin{tabular}{|c|c|c|c|c|c|c|c|}
\hline Traits & \multicolumn{1}{|c|}{$\begin{array}{c}\text { No. of } \\
\text { pods/plant } \\
\text { Treatments }\end{array}$} & $\begin{array}{c}\text { Weight of } \\
\text { pods/plant } \\
(\mathbf{g})\end{array}$ & $\begin{array}{c}\text { Weight of } \\
\text { seeds/ } \\
\text { plant } \\
(\mathbf{g})\end{array}$ & $\begin{array}{c}\text { Weight } \\
\text { of 100- } \\
\text { seed } \\
\text { (g) }\end{array}$ & $\begin{array}{c}\text { Pod yield } \\
\text { (ton/fed) }\end{array}$ & $\begin{array}{c}\text { Straw } \\
\text { yield } \\
\text { (ton/fed) }\end{array}$ \\
\hline $\begin{array}{c}\text { Inter. } \\
\text { patterns }\end{array}$ & \multicolumn{2}{|c|}{ First season 2003 } \\
\hline $\begin{array}{c}100 \%: 33 \% \\
(2: 1)\end{array}$ & $17.45 \mathrm{~A}$ & $21.51 \mathrm{~A}$ & $16.32 \mathrm{~A}$ & $66.68 \mathrm{~A}$ & $1.06 \mathrm{~A}$ & $1.00 \mathrm{~A}$ \\
\hline $\begin{array}{c}100 \%: 50 \% \\
(1: 1)\end{array}$ & $15.60 \mathrm{~B}$ & $20.41 \mathrm{~B}$ & $14.69 \mathrm{~B}$ & $65.78 \mathrm{~B}$ & $1.01 \mathrm{~B}$ & $0.95 \mathrm{~B}$ \\
\hline $\begin{array}{c}100 \%: 67 \% \\
(1: 2)\end{array}$ & $11.50 \mathrm{C}$ & $17.32 \mathrm{C}$ & $10.57 \mathrm{C}$ & $63.27 \mathrm{C}$ & $0.86 \mathrm{C}$ & $0.80 \mathrm{C}$ \\
\hline $\begin{array}{c}100 \%: 33 \% \\
(2: 1)\end{array}$ & $15.05 \mathrm{~A}$ & $18.48 \mathrm{~A}$ & $13.85 \mathrm{~A}$ & $60.54 \mathrm{~A}$ & $0.91 \mathrm{~A}$ & $0.85 \mathrm{~A}$ \\
\hline $\begin{array}{c}100 \%: 50 \% \\
(1: 1)\end{array}$ & $13.44 \mathrm{~B}$ & $17.54 \mathrm{~B}$ & $12.47 \mathrm{~B}$ & $59.48 \mathrm{~B}$ & $0.85 \mathrm{~B}$ & $0.80 \mathrm{~B}$ \\
\hline $\begin{array}{c}100 \%: 67 \% \\
(1: 2)\end{array}$ & $9.87 \mathrm{C}$ & $14.88 \mathrm{C}$ & $8.97 \mathrm{C}$ & $58.07 \mathrm{C}$ & $0.72 \mathrm{C}$ & $0.67 \mathrm{C}$ \\
\hline
\end{tabular}

Effect of orientation of maize plants

Results in Table 2 indicate that yield and its component traits were influenced by the geometric distribution of maize. Values of these traits when maize plants were spaced at $70 \mathrm{~cm}$ apart with leaving two plants per each hill were ever superior to those spaced at $35 \mathrm{~cm}$ and leaving one plant/hill, except, the filling percent where the trend was truly reversed.

Egypt. J. Agron. 34, No. 1 (2012) 
TABLE 2. Effect of orientation of maize plants on yield and yield component traits of peanut in 2003 and 2004 seasons.

\begin{tabular}{|c|c|c|c|c|c|c|}
\hline & \multicolumn{1}{|c|}{$\begin{array}{c}\text { No.of } \\
\text { pods/plat }\end{array}$} & $\begin{array}{c}\text { Weight of } \\
\text { pods/ } \\
\text { plant } \text { (g) }\end{array}$ & $\begin{array}{c}\text { Weight of } \\
\text { seeds/ } \\
\text { plant (g) }\end{array}$ & $\begin{array}{c}\text { Weight of } \\
\text { 100-seed } \\
\text { (g) }\end{array}$ & $\begin{array}{c}\text { Pod yield } \\
\text { (ton/fed) }\end{array}$ & $\begin{array}{c}\text { Straw } \\
\text { yield } \\
\text { (ton/fed) }\end{array}$ \\
\hline $\begin{array}{c}\text { Orient. of } \\
\text { maize plants }\end{array}$ & $11.87 \mathrm{~B}$ & $17.35 \mathrm{~B}$ & $12.73 \mathrm{~B}$ & $58.54 \mathrm{~B}$ & $0.83 \mathrm{~B}$ & $0.78 \mathrm{~B}$ \\
\hline $\begin{array}{c}35 \mathrm{~cm} \text { apart } \\
\text { (one } \\
\text { plant/hill) }\end{array}$ & $17.83 \mathrm{~A}$ & $22.15 \mathrm{~A}$ & $14.99 \mathrm{~A}$ & $71.94 \mathrm{~A}$ & $1.12 \mathrm{~A}$ & $1.05 \mathrm{~A}$ \\
\hline $\begin{array}{c}70 \mathrm{~cm} \text { apart } \\
\text { (two } \\
\text { plants/hill) }\end{array}$ & $10.22 \mathrm{~B}$ & $14.90 \mathrm{~B}$ & $10.81 \mathrm{~B}$ & $53.27 \mathrm{~B}$ & $0.71 \mathrm{~B}$ & $0.66 \mathrm{~B}$ \\
\hline $\begin{array}{c}35 \mathrm{~cm} \text { apart } \\
\text { (one } \\
\text { plant/hill) }\end{array}$ & $15.36 \mathrm{~A}$ & $19.03 \mathrm{~A}$ & $12.72 \mathrm{~A}$ & $65.46 \mathrm{~A}$ & $0.95 \mathrm{~A}$ & $0.89 \mathrm{~A}$ \\
\hline $\begin{array}{c}70 \mathrm{~cm} \text { apart } \\
\text { (two } \\
\text { plants/hill) }\end{array}$ & \multicolumn{2}{|c|}{ Second season 2004 } \\
\hline
\end{tabular}

Pod and straw yield of peanut spaced at $70 \mathrm{~cm}$ and leaving two plants per hill surpassed that spaced at $35 \mathrm{~cm}$ and leaving one plant per hill by 0.29 and 0.27 ton/fed, respectively in the first season as well as 0.24 and 0.23 ton/fed in the second one. These results are in agreement with those obtained by Sherif et al. (2005).

In explicit, these results evidenced that reductions in values of these traits were tenaciously bounded with narrowing maize spacing which resulted in more shading. Calavan \& Weil (1988), support the conclusion that the within-row maize spacing treatments significantly affected light availability to peanut plants.

In addition Hardy \& Havelka (1973), reported that shading reduces the rate of peanut photosynthesis and affects the amount of assimilates available for the competing processes of $\mathrm{N}_{2}$ fixation and reproductive dry matter accumulation. They also found that peanut root nitrogenase activity was 30 to $46 \%$ lower for intercrop than for sole crop.

Effect of nitrogen fertilizer levels

Results presented in Table 3 indicated that peanut in the intercrop was responsive to nitrogen fertilizer. Moreover, there were ever increases in the values of yield and its component traits with increasing the level of nitrogen fertilizer up to $120 \mathrm{~kg} \mathrm{~N} / \mathrm{fed}$. These results were true in both seasons. This result may be due to the role of nitrogen element in enhancing the meristmatic activity of plant tissues which contributes to the production of new organs as well as to the role of nitrogen in stimulating the metabolic activity which are used in building up plant organs such as tillers flowers and pods. The response in yield components traits and yield/fed were supported by several investigators such as Abd El-Motaleb \& Yousef (1998), Hussein, Samira (2005) and Lanier et al. (2005).

Egypt. J. Agron. 34, No. 1 (2012) 
TABLE 3. Effect of nitrogen fertilizer levels on yield and yield component traits of peanut in 2003 and 2004 seasons.

\begin{tabular}{|c|c|c|c|c|c|c|}
\hline Treatments & $\begin{array}{l}\text { No.of } \\
\text { pods/ } \\
\text { plant }\end{array}$ & $\begin{array}{c}\text { Weight of } \\
\text { pods/ } \\
\text { plant (g) }\end{array}$ & $\begin{array}{c}\text { Weight of } \\
\text { seeds / } \\
\text { plant } \\
\text { (g) }\end{array}$ & $\begin{array}{c}\text { Weight of } \\
\text { 100-seed } \\
\text { (g) }\end{array}$ & $\begin{array}{c}\text { Pod yield } \\
\text { (ton/fed) }\end{array}$ & $\begin{array}{c}\text { Straw } \\
\text { yield } \\
\text { (ton/fed) }\end{array}$ \\
\hline $\mathrm{N}$ fert. levels & \multicolumn{6}{|c|}{ First season 2003} \\
\hline $60 \mathrm{~kg} / \mathrm{fed}$ & $14.11 \mathrm{C}$ & $18.35 \mathrm{C}$ & $12.47 \mathrm{C}$ & $63.65 \mathrm{C}$ & $0.90 \mathrm{C}$ & $0.85 \mathrm{C}$ \\
\hline $90 \mathrm{~kg} / \mathrm{fed}$. & $14.85 \mathrm{~B}$ & $20.25 \mathrm{~B}$ & $14.28 \mathrm{~B}$ & $65.25 \mathrm{~B}$ & $1.00 \mathrm{~B}$ & $0.94 \mathrm{~B}$ \\
\hline \multirow[t]{2}{*}{$120 \mathrm{~kg} / \mathrm{fed}$} & $15.59 \mathrm{~A}$ & $20.65 \mathrm{~A}$ & $14.84 \mathrm{~A}$ & $66.82 \mathrm{~A}$ & $1.02 \mathrm{~A}$ & $0.96 \mathrm{~A}$ \\
\hline & \multicolumn{6}{|c|}{ Second season 2004} \\
\hline $60 \mathrm{~kg} / \mathrm{fed}$ & $12.15 \mathrm{C}$ & $15.76 \mathrm{C}$ & $10.58 \mathrm{C}$ & $57.92 \mathrm{C}$ & $0.77 \mathrm{~B}$ & $0.72 \mathrm{~B}$ \\
\hline $90 \mathrm{~kg} / \mathrm{fed}$ & $12.77 \mathrm{~B}$ & $17.39 \mathrm{~B}$ & $12.12 \mathrm{~B}$ & $59.37 \mathrm{~B}$ & $0.85 \mathrm{~A}$ & $0.80 \mathrm{~A}$ \\
\hline $120 \mathrm{~kg} / \mathrm{fed}$ & $13.44 \mathrm{~A}$ & $17.74 \mathrm{~A}$ & $12.60 \mathrm{~A}$ & $60.81 \mathrm{~A}$ & $0.87 \mathrm{~A}$ & $0.81 \mathrm{~A}$ \\
\hline
\end{tabular}

Patra \& Poi (1998) revealed that intercropping caused the number of nitrogen fixing nodules on the legume crop roots to decrease due to shading. When legume was intercropped with cereals, legume nodulation was poor and less nitrogen fixation took place. On this basic ground, it could be concluded that First: intercropping peanut with maize might stimulate the peanut plant response to increased levels of nitrogen fertilizer rather than growing peanut in mono culture due to the inhibitory effect of maize shading on peanut nodulation, (Senaratne \& Ratnasinghe, 1993). Second: that the poor natural population of rhizobia in the sandy soil was offset by high response of peanut to increased nitrogen fertilizer level might explain different response to the nitrogen fertilizer level. These conclusions were also explained by Senaratne \& Ratnasinghe (1993).

\section{Interaction effects}

A summary of the interaction effects of the three factors is given in Table 4 . The highest values of traits studied are given. The letters in brackets represent the sequence in the order of the planting practices (intercropping patterns $\times$ orientation of maize plants $\times$ nitrogen fertilizer levels). From the table it is clear that the highest values of yield and its components traits were recorded when maize percent in the intercrop diminished to one third of its full stand in (2:1) pattern, when only growing maize at $70 \mathrm{~cm}$ apart and leaving two plants/hill and received $120 \mathrm{~kg} \mathrm{~N} / \mathrm{fed}$. Similar conclusions were also explained by Abd El-Motaleb \& Yousef (1998) and Hussein et al. (2002). 
TABLE 4. Summary of interaction effects among intercropping patterns (A), orientation of maize plants $(B)$ and nitrogen fertilizer levels $(C)$ on yield and yield component traits of peanut in 2003 and 2004 seasons.

\begin{tabular}{|c|c|c|c|c|c|c|}
\hline Traits & $\begin{array}{c}\text { No.of } \\
\text { pods/plant }\end{array}$ & $\begin{array}{c}\text { Weight of } \\
\text { pods/plant } \\
\text { (g) }\end{array}$ & $\begin{array}{c}\text { Weight of } \\
\text { seeds / } \\
\text { plant (g) }\end{array}$ & $\begin{array}{c}\text { Weight of } \\
100 \text {-seed }(g)\end{array}$ & $\begin{array}{c}\text { Pod yield } \\
\text { (ton/fed) }\end{array}$ & $\begin{array}{c}\text { Straw yield } \\
\text { (ton/fed) }\end{array}$ \\
\hline & \multicolumn{6}{|c|}{ First season 2003} \\
\hline $\mathrm{A} \times \mathrm{B}$ & $\begin{array}{c}\left(\mathrm{A}_{1} \times \mathrm{B}_{2}\right) \\
20.68\end{array}$ & $\begin{array}{c}\left(\mathrm{A}_{1} \times \mathrm{B}_{2}\right) \\
24.10\end{array}$ & $\begin{array}{c}\left(\mathrm{A}_{1} \times \mathrm{B}_{2}\right) \\
17.61\end{array}$ & $\begin{array}{c}\left(\mathrm{A}_{1} \times \mathrm{B}_{2}\right) \\
73.52\end{array}$ & $\begin{array}{c}{ }^{*}\left(\mathrm{~A}_{1} \times \mathrm{B}_{2}\right) \\
1.21\end{array}$ & $\begin{array}{c}\left(\mathrm{A}_{1} \times \mathrm{B}_{2}\right) \\
1.14\end{array}$ \\
\hline $\mathrm{A} \times \mathrm{C}$ & $\begin{array}{c}\left(\mathrm{A}_{1} \times \mathrm{C}_{3}\right) \\
18.35 \\
\end{array}$ & $\begin{array}{c}\left(\mathrm{A}_{1} \times \mathrm{C}_{3}\right) \\
22.48 \\
\end{array}$ & $\begin{array}{c}\left(\mathrm{A}_{1} \times \mathrm{C}_{3}\right) \\
17.43 \\
\end{array}$ & $\begin{array}{c}\left(\mathrm{A}_{1} \times \mathrm{C}_{3}\right) \\
68.14 \\
\end{array}$ & $\begin{array}{c}\left(\mathrm{A}_{1} \times \mathrm{C}_{3}\right) \\
1.11\end{array}$ & $\begin{array}{c}\left(\mathrm{A}_{1} \times \mathrm{C}_{3}\right) \\
1.04 \\
\end{array}$ \\
\hline $\mathrm{B} \times \mathrm{C}$ & $\begin{array}{c}\left(\mathrm{B}_{2} \times \mathrm{C}_{3}\right) \\
18.82 \\
\end{array}$ & $\begin{array}{c}\left(\mathrm{B}_{2} \times \mathrm{C}_{3}\right) \\
23.14\end{array}$ & $\begin{array}{c}\left(\mathrm{B}_{2} \times \mathrm{C}_{3}\right) \\
16.03\end{array}$ & $\begin{array}{c}\left(\mathrm{B}_{2} \times \mathrm{C}_{3}\right) \\
73.67\end{array}$ & $\begin{array}{c}{ }^{*}\left(\mathrm{~B}_{2} \times \mathrm{C}_{3}\right) \\
1.17\end{array}$ & $\begin{array}{c}\left(\mathrm{B}_{2} \times \mathrm{C}_{3}\right) \\
1.09\end{array}$ \\
\hline $\mathrm{A} \times \mathrm{B} \times \mathrm{C}$ & $\begin{array}{c}\left(\mathrm{A}_{1} \times \mathrm{B}_{2} \times \mathrm{C}_{3}\right) \\
21.65\end{array}$ & $\begin{array}{c}\left(\mathrm{A}_{1} \times \mathrm{B}_{2} \times \mathrm{C}_{3}\right) \\
25.15\end{array}$ & $\begin{array}{c}\left(\mathrm{A}_{1} \times \mathrm{B}_{2} \times \mathrm{C}_{3}\right) \\
18.79\end{array}$ & $\begin{array}{c}\left(\mathrm{A}_{1} \times \mathrm{B}_{2} \times \mathrm{C}_{3}\right) \\
75.10\end{array}$ & $\begin{array}{c}\left(\mathrm{A}_{1} \times \mathrm{B}_{2} \times \mathrm{C}_{3}\right) \\
1.27\end{array}$ & $\begin{array}{c}\left(\mathrm{A}_{1} \times \mathrm{B}_{2} \times \mathrm{C}_{3}\right) \\
1.19\end{array}$ \\
\hline \multicolumn{7}{|c|}{ Second season 2004} \\
\hline$A \times B$ & $\begin{array}{c}\left(\mathrm{A}_{1} \times \mathrm{B}_{2}\right) \\
17.86 \\
\end{array}$ & $\begin{array}{c}\left(A_{1} \times B_{2}\right) \\
20.71 \\
\end{array}$ & $\begin{array}{c}\left(\mathrm{A}_{1} \times \mathrm{B}_{2}\right) \\
14.95 \\
\end{array}$ & $\begin{array}{c}\left(A_{1} \times B_{2}\right) \\
66.77 \\
\end{array}$ & $\begin{array}{c}\left(\mathrm{A}_{1} \times \mathrm{B}_{2}\right) \\
1.04\end{array}$ & $\begin{array}{c}\left(\mathrm{A}_{1} \times \mathrm{B}_{2}\right) \\
0.98\end{array}$ \\
\hline $\mathrm{A} \times \mathrm{C}$ & $\begin{array}{c}\left(\mathrm{A}_{1} \times \mathrm{C}_{3}\right) \\
15.79\end{array}$ & $\begin{array}{c}\left(\mathrm{A}_{1} \times \mathrm{C}_{3}\right) \\
19.31\end{array}$ & $\begin{array}{c}\left(\mathrm{A}_{1} \times \mathrm{C}_{3}\right) \\
14.81\end{array}$ & $\begin{array}{c}\left(\mathrm{A}_{1} \times \mathrm{C}_{3}\right) \\
61.87\end{array}$ & $\begin{array}{c}\left(\mathrm{A}_{1} \times \mathrm{C}_{3}\right) \\
0.95\end{array}$ & $\begin{array}{c}\left(\mathrm{A}_{1} \times \mathrm{C}_{3}\right) \\
0.89\end{array}$ \\
\hline $\mathrm{B} \times \mathrm{C}$ & $\begin{array}{c}\left(\mathrm{B}_{2} \times \mathrm{C}_{3}\right) \\
16.10 \\
\end{array}$ & $\begin{array}{c}\left(\mathrm{B}_{2} \times \mathrm{C}_{3}\right) \\
19.88 \\
\end{array}$ & $\begin{array}{c}\left(\mathrm{B}_{2} \times \mathrm{C}_{3}\right) \\
13.60 \\
\end{array}$ & $\begin{array}{c}\left(\mathrm{B}_{2} \times \mathrm{C}_{3}\right) \\
67.03 \\
\end{array}$ & $\begin{array}{c}\left(\mathrm{B}_{2} \times \mathrm{C}_{3}\right) \\
0.99 \\
\end{array}$ & $\begin{array}{c}\left(\mathrm{B}_{2} \times \mathrm{C}_{3}\right) \\
0.93 \\
\end{array}$ \\
\hline $\mathrm{A} \times \mathrm{B} \times \mathrm{C}$ & $\begin{array}{c}\left(\mathrm{A}_{1} \times \mathrm{B}_{2} \times \mathrm{C}_{3}\right) \\
18.71\end{array}$ & $\begin{array}{c}\left(\mathrm{A}_{1} \times \mathrm{B}_{2} \times \mathrm{C}_{3}\right) \\
21.60\end{array}$ & $\begin{array}{c}\left(\mathrm{A}_{1} \times \mathrm{B}_{2} \times \mathrm{C}_{3}\right) \\
15.96\end{array}$ & $\begin{array}{c}\left(\mathrm{A}_{1} \times \mathrm{B}_{2} \times \mathrm{C}_{3}\right) \\
68.22\end{array}$ & $\begin{array}{c}\left(\mathrm{A}_{1} \times \mathrm{B}_{2} \times \mathrm{C}_{3}\right) \\
1.09\end{array}$ & $\begin{array}{c}\left(\mathrm{A}_{1} \times \mathrm{B}_{2} \times \mathrm{C}_{3}\right) \\
1.03\end{array}$ \\
\hline
\end{tabular}

Maize

Effect of intercropping patterns

Results in Table 5 indicate that the values of all yield components decreased with increasing maize density in the intercrop. Consequently maximum values of these traits were obtained with $33 \%$ maize in $(2: 1)$ pattern, while, the minimum values were obtained in $(1: 2)$ pattern with $67 \%$ maize density. The results hold true in both seasons. Since plant density was the principal mode of action within the intercrop, responses of maize yield components were mostly due to maize density. The increase in maize yield components values may be due to the decrease in maize density could be due attributed to less competition between plants for light, water, nutrient minerals and place. The similar results were obtained by several investigators. El-Hosary \& Salwau (1989), El-Bana \& Gomaa (2000) and Ibrahim \& Abd El-Maksoud (2001) demonstrated that maize yield component, increased with decreasing maize density in the intercrop.

Results on grain and straw yields/fed followed reversed trends of the pattern treatment effect on maize yield components.

The results indicate maximum yield with increasing maize density in the pattern, with (67\% maize density) whilist minimum yield was associated with pattern (2:1) with $33 \%$ maize density indicating that the yields were associated with maize density in the intercrop rather than any other factor. These results are in agreement with those obtained by several investigators such as Lucas (1986) and El-Bana \& Gomaa (2000). 
TABLE 5. Effect of intercropping patterns on yield and yield component traits of maize in 2003 and 2004 seasons.

\begin{tabular}{|c|c|c|c|c|c|c|c|}
\hline & \multicolumn{1}{|c|}{$\begin{array}{c}\text { Ear } \\
\text { length } \\
(\mathbf{c m})\end{array}$} & $\begin{array}{c}\text { Ear } \\
\text { diameter } \\
(\mathbf{c m})\end{array}$ & $\begin{array}{c}\text { Ear } \\
\text { weight } \\
(\mathbf{g})\end{array}$ & $\begin{array}{c}\text { Weight of } \\
\text { kernels / } \\
\text { ear }(\mathbf{g})\end{array}$ & $\begin{array}{c}\text { 100- } \\
\text { kernel } \\
\text { weight } \\
(\mathbf{g})\end{array}$ & $\begin{array}{c}\text { Grain } \\
\text { yield } \\
\text { ton/fed) }\end{array}$ & $\begin{array}{c}\text { Straw } \\
\text { yield } \\
\text { (ton/fed) }\end{array}$ \\
\hline $\begin{array}{c}\text { Inter. patterns } \\
\text { Peanut : Maize }\end{array}$ & \multicolumn{7}{|c|}{ First season 2003 } \\
\hline $\begin{array}{c}100 \%: 33 \% \\
(2: 1)\end{array}$ & $17.74 \mathrm{~A}$ & $3.85 \mathrm{~A}$ & $219.99 \mathrm{~A}$ & $179.23 \mathrm{~A}$ & $32.18 \mathrm{~A}$ & $1.17 \mathrm{C}$ & $0.87 \mathrm{C}$ \\
\hline $\begin{array}{c}100 \%: 50 \% \\
(1: 1)\end{array}$ & $16.66 \mathrm{~B}$ & $3.67 \mathrm{~A}$ & $197.05 \mathrm{~B}$ & $157.67 \mathrm{~B}$ & $31.43 \mathrm{~B}$ & $1.54 \mathrm{~B}$ & $1.15 \mathrm{~B}$ \\
\hline $\begin{array}{c}100 \%: 67 \% \\
(1: 2)\end{array}$ & $15.58 \mathrm{C}$ & $3.31 \mathrm{~B}$ & $178.84 \mathrm{C}$ & $142.59 \mathrm{C}$ & $30.28 \mathrm{C}$ & $1.86 \mathrm{~A}$ & $1.36 \mathrm{~A}$ \\
\hline $\begin{array}{c}100 \%: 33 \% \\
(2: 1)\end{array}$ & $18.48 \mathrm{~A}$ & $3.90 \mathrm{~A}$ & $251.53 \mathrm{~A}$ & $201.86 \mathrm{~A}$ & $34.80 \mathrm{~A}$ & $1.33 \mathrm{C}$ & $0.98 \mathrm{C}$ \\
\hline $\begin{array}{c}100 \%: 50 \% \\
(1: 1)\end{array}$ & $17.13 \mathrm{~B}$ & $3.75 \mathrm{~A}$ & $224.24 \mathrm{~B}$ & $176.68 \mathrm{~B}$ & $33.98 \mathrm{~B}$ & $1.75 \mathrm{~B}$ & $1.31 \mathrm{~B}$ \\
\hline $\begin{array}{c}100 \%: 67 \% \\
(1: 2)\end{array}$ & $15.78 \mathrm{C}$ & $3.42 \mathrm{~B}$ & $197.96 \mathrm{C}$ & $155.46 \mathrm{C}$ & $32.88 \mathrm{C}$ & $2.05 \mathrm{~A}$ & $1.54 \mathrm{~A}$ \\
\hline
\end{tabular}

Effect of orientation of maize plants

Results in Table 6 indicate that maize yields and its components were significantly influenced by maize orientation in the intercrop in both seasons, except, ear diameter, differences failed to reach the 5\% level in both seasons. The results indicate that values of all yield and its components traits when maize was spaced at $35 \mathrm{~cm}$ apart with one plant/hill except in case of 100-kernel weight were always higher than those recorded when maize was spaced at $70 \mathrm{~cm}$ apart with two plants/hill. These observations were valid in both seasons.

TABLE 6. Effect of orientation of maize plants on yield and yield component traits of maize in 2003 and 2004 seasons.

\begin{tabular}{|c|c|c|c|c|c|c|c|}
\hline & \multicolumn{1}{|c|}{$\begin{array}{c}\text { Ear } \\
\text { (ength } \\
\text { Treatments }\end{array}$} & $\begin{array}{c}\text { Ear } \\
\text { diameter } \\
\text { (cm) }\end{array}$ & $\begin{array}{c}\text { Ear } \\
\text { weight } \\
\text { (g) }\end{array}$ & $\begin{array}{c}\text { Weight } \\
\text { of } \\
\text { kernels / } \\
\text { ear (g) }\end{array}$ & $\begin{array}{c}\text { 100- } \\
\text { kernel } \\
\text { weight } \\
\text { (g) }\end{array}$ & $\begin{array}{c}\text { Grain } \\
\text { yield } \\
\text { (ton/fed) }\end{array}$ & $\begin{array}{c}\text { Straw } \\
\text { yield } \\
\text { (ton/fed) }\end{array}$ \\
\hline $\begin{array}{c}\text { Orient. of } \\
\text { maize plants }\end{array}$ & \multicolumn{7}{|c|}{ First season 2003 } \\
\hline $\begin{array}{c}35 \mathrm{~cm} \\
\text { apart (one } \\
\text { plant/hill) }\end{array}$ & $17.12 \mathrm{~A}$ & $3.65 \mathrm{~A}$ & $204.74 \mathrm{~A}$ & $166.12 \mathrm{~A}$ & $30.79 \mathrm{~B}$ & $1.58 \mathrm{~A}$ & $1.18 \mathrm{~A}$ \\
\hline $\begin{array}{c}70 \mathrm{~cm} \\
\text { apart (two } \\
\text { plants/hill) }\end{array}$ & $16.21 \mathrm{~B}$ & $3.57 \mathrm{~A}$ & $192.51 \mathrm{~B}$ & $153.55 \mathrm{~B}$ & $31.80 \mathrm{~A}$ & $1.47 \mathrm{~B}$ & $1.07 \mathrm{~B}$ \\
\hline $\begin{array}{c}35 \mathrm{~cm} \\
\text { apart(one } \\
\text { plant/hill) }\end{array}$ & $17.40 \mathrm{~A}$ & $3.72 \mathrm{~A}$ & $235.88 \mathrm{~A}$ & $188.49 \mathrm{~A}$ & $33.01 \mathrm{~B}$ & $1.80 \mathrm{~A}$ & $1.34 \mathrm{~A}$ \\
\hline $\begin{array}{c}70 \mathrm{~cm} \\
\text { apart (two } \\
\text { plants/hill) }\end{array}$ & $16.86 \mathrm{~B}$ & $3.66 \mathrm{~A}$ & $213.28 \mathrm{~B}$ & $167.51 \mathrm{~B}$ & $34.76 \mathrm{~A}$ & $1.63 \mathrm{~B}$ & $1.21 \mathrm{~B}$ \\
\hline
\end{tabular}

Egypt. J. Agron. 34, No. 1 (2012) 
These results seemed distinctive and did not coincide with light penetration theory only which over dominated most of the results. Interpretation might be due the diminishing effect as a result of plant to plant competition when two plants were left per hill and maize was orientated at $70 \mathrm{~cm}$ spacing. Hussein et al. (2002) and Sherif et al. (2005) came to similar results.

Effect of nitrogen fertilization levels

Results in Table 7 obtained that there were increases in all yield and its components traits with increasing nitrogen fertilizer dose up to $120 \mathrm{~kg} \mathrm{~N} / \mathrm{fed}$. Increases were significant among the treatment imposed in both seasons, except, in case of ear diameter where differences failed to reach $5 \%$ level of significance. The increases in yield and its components of maize with increasing $\mathrm{N}$ level are mainly due to role of $\mathrm{N}$ in stimulating metabolic activity which contributed to the increase in metabolites amount most of which is used building yield and its components. These results were in agreement with several investigators such ElDouby et al. (2001), Shams (2002) and Hussein (2005).

TABLE 7. Effect of nitrogen fertilizer levels on yield and yield component traits of maize in 2003 and 2004 seasons.

\begin{tabular}{|c|c|c|c|c|c|c|c|}
\hline Traits & $\begin{array}{c}\text { Ear } \\
\text { length } \\
\text { (cm) }\end{array}$ & $\begin{array}{c}\text { Ear } \\
\text { diameter } \\
(\mathbf{c m})\end{array}$ & $\begin{array}{c}\text { Ear } \\
\text { weight } \\
\text { (g) }\end{array}$ & $\begin{array}{c}\begin{array}{c}\text { Weight } \\
\text { of }\end{array} \\
\text { kernels / } \\
\text { ear } \\
\text { (g) } \\
\end{array}$ & $\begin{array}{c}\text { 100- } \\
\text { kernel } \\
\text { weight } \\
\text { (g) }\end{array}$ & $\begin{array}{c}\text { Grain } \\
\text { yield } \\
\text { (ton/fed) }\end{array}$ & $\begin{array}{c}\text { Straw } \\
\text { yield } \\
\text { (ton/fed) }\end{array}$ \\
\hline $\mathrm{N}$ fert. levels & \multicolumn{7}{|c|}{ First season 2003} \\
\hline $60 \mathrm{~kg} / \mathrm{fed}$ & $15.84 \mathrm{C}$ & $3.56 \mathrm{~A}$ & $179.11 \mathrm{C}$ & $143.51 \mathrm{C}$ & $30.03 \mathrm{C}$ & $1.37 \mathrm{C}$ & $1.03 \mathrm{~B}$ \\
\hline $90 \mathrm{~kg} / \mathrm{fed}$ & $16.71 \mathrm{~B}$ & $3.58 \mathrm{~A}$ & $199.29 \mathrm{~B}$ & $160.31 \mathrm{~B}$ & $31.63 \mathrm{~B}$ & $1.53 \mathrm{~B}$ & $1.13 \mathrm{~A}$ \\
\hline \multirow[t]{2}{*}{$120 \mathrm{~kg} / \mathrm{fed}$} & $17.43 \mathrm{~A}$ & $3.70 \mathrm{~A}$ & $217.47 \mathrm{~A}$ & $175.68 \mathrm{~A}$ & $32.23 \mathrm{~A}$ & $1.67 \mathrm{~A}$ & $1.21 \mathrm{~A}$ \\
\hline & \multicolumn{7}{|c|}{ Second season 2004} \\
\hline $60 \mathrm{~kg} / \mathrm{fed}$ & $16.29 \mathrm{C}$ & $3.63 \mathrm{~A}$ & $211.00 \mathrm{C}$ & $166.59 \mathrm{C}$ & $32.85 \mathrm{C}$ & $1.60 \mathrm{C}$ & $1.19 \mathrm{C}$ \\
\hline $90 \mathrm{~kg} / \mathrm{fed}$ & $17.17 \mathrm{~B}$ & $3.65 \mathrm{~A}$ & $226.19 \mathrm{~B}$ & $179.30 \mathrm{~B}$ & $34.08 \mathrm{~B}$ & $1.72 \mathrm{~B}$ & $1.28 \mathrm{~B}$ \\
\hline $120 \mathrm{~kg} / \mathrm{fed}$ & $17.93 \mathrm{~A}$ & $3.79 \mathrm{~A}$ & $236.55 \mathrm{~A}$ & $188.10 \mathrm{~A}$ & $34.73 \mathrm{~A}$ & $1.81 \mathrm{~A}$ & $1.36 \mathrm{~A}$ \\
\hline
\end{tabular}

Interaction effects

A summary of the interaction effects of the three experimental factors is given in Table 8. The highest values of traits studied are given. The letters in brackets represent the sequence in the order of the planting practices (intercropping patterns $\times$ orientation of maize plants $\times$ nitrogen fertilizer levels).

It is clear that the highest values of yield components traits were recorded when maize percent in the intercrop diminished to $33 \%$ of its full stand in $(2: 1)$ pattern when only growing maize at $35 \mathrm{~cm}$ apart, leaving one plant/hill and received $120 \mathrm{~kg}$ $\mathrm{N} /$ fed while grain and straw yields/fed reached maximum when maize percent in the intercrop increased to $67 \%$ of its full stand in (1:2) pattern when only growing maize at $35 \mathrm{~cm}$ apart and leaving one plant/hill and received $120 \mathrm{~kg} \mathrm{~N} / \mathrm{fed}$. These results coincide with those explained by Eliseu \& Freire (1992) and Metwally et al. (2005). 
TABLE 8. Summary of interaction effects among intercropping patterns (A), orientation of maize plants $(B)$ and nitrogen fertilizer levels $(C)$ on yield and yield component traits of maize in 2003 and 2004 seasons.

\begin{tabular}{|c|c|c|c|c|c|c|c|}
\hline Traits & $\begin{array}{c}\text { Ear } \\
\text { length } \\
(\mathrm{cm})\end{array}$ & $\begin{array}{c}\text { Ear } \\
\text { diameter } \\
(\mathbf{c m})\end{array}$ & $\begin{array}{c}\text { Ear } \\
\text { weight } \\
\text { (g) }\end{array}$ & $\begin{array}{l}\text { Weight of } \\
\text { kernels / } \\
\text { ear } \\
\text { (g) }\end{array}$ & $\begin{array}{c}100- \\
\text { kernel } \\
\text { weight } \\
\text { (g) }\end{array}$ & $\begin{array}{c}\text { Grain } \\
\text { yield } \\
\text { (ton/fed) }\end{array}$ & $\begin{array}{c}\text { Straw } \\
\text { yield } \\
\text { (ton/fed) }\end{array}$ \\
\hline & \multicolumn{7}{|c|}{ First season 2003} \\
\hline $\mathrm{A} \times \mathrm{B}$ & $\begin{array}{c}\left(\mathrm{A}_{1} \times \mathrm{B}_{1}\right) \\
18.23\end{array}$ & $\begin{array}{c}\left(\mathrm{A}_{1} \times \mathrm{B}_{1}\right) \\
3.89\end{array}$ & $\begin{array}{c}\left(\mathrm{A}_{1} \times \mathrm{B}_{1}\right) \\
231.75\end{array}$ & $\begin{array}{c}\left(\mathrm{A}_{1} \times \mathrm{B}_{1}\right) \\
191.51\end{array}$ & $\begin{array}{c}\left(\mathrm{A}_{1} \times \mathrm{B}_{2}\right) \\
32.65\end{array}$ & $\begin{array}{c}\left(\mathrm{A}_{3} \times \mathrm{B}_{1}\right) \\
1.87\end{array}$ & $\begin{array}{c}\left(\mathrm{A}_{3} \times \mathrm{B}_{1}\right) \\
1.39\end{array}$ \\
\hline $\mathrm{A} \times \mathrm{C}$ & $\begin{array}{c}\left(\mathrm{A}_{1} \times \mathrm{C}_{3}\right) \\
18.58\end{array}$ & $\begin{array}{c}\left(\mathrm{A}_{1} \times \mathrm{C}_{3}\right) \\
3.95\end{array}$ & $\begin{array}{c}\left(\mathrm{A}_{1} \times \mathrm{C}_{3}\right) \\
243.02\end{array}$ & $\begin{array}{c}\left(\mathrm{A}_{1} \times \mathrm{C}_{3}\right) \\
198.82\end{array}$ & $\begin{array}{c}\left(\mathrm{A}_{1} \times \mathrm{C}_{3}\right) \\
33.22\end{array}$ & $\begin{array}{c}\left(\mathrm{A}_{3} \times \mathrm{C}_{3}\right) \\
2.02\end{array}$ & $\begin{array}{c}\left(\mathrm{A}_{3} \times \mathrm{C}_{3}\right) \\
1.46\end{array}$ \\
\hline $\mathrm{B} \times \mathrm{C}$ & $\begin{array}{c}\left(\mathrm{B}_{1} \times \mathrm{C}_{3}\right) \\
17.92\end{array}$ & $\begin{array}{c}\text { NS. }\left(B_{1} \times C_{3}\right) \\
3.74\end{array}$ & $\begin{array}{c}\left(\mathrm{B}_{1} \times \mathrm{C}_{3}\right) \\
224.29\end{array}$ & $\begin{array}{c}\left(\mathrm{B}_{1} \times \mathrm{C}_{3}\right) \\
182.75\end{array}$ & $\begin{array}{c}\left(\mathrm{B}_{2} \times \mathrm{C}_{3}\right) \\
32.82\end{array}$ & $\begin{array}{c}\left(\mathrm{B}_{1} \times \mathrm{C}_{3}\right) \\
1.73\end{array}$ & $\begin{array}{c}\left(\mathrm{B}_{1} \times \mathrm{C}_{3}\right) \\
1.27\end{array}$ \\
\hline \multirow[t]{2}{*}{$\mathrm{A} \times \mathrm{B} \times \mathrm{C}$} & $\begin{array}{c}\left(\mathrm{A}_{1} \times \mathrm{B}_{1} \times \mathrm{C}_{3}\right) \\
19.10\end{array}$ & $\begin{array}{c}\left(\mathrm{A}_{1} \times \mathrm{B}_{1} \times \mathrm{C}_{3}\right) \\
3.99\end{array}$ & $\begin{array}{c}\left(\mathrm{A}_{1} \times \mathrm{B}_{1} \times \mathrm{C}_{3}\right) \\
256.17\end{array}$ & $\begin{array}{c}\left(\mathrm{A}_{1} \times \mathrm{B}_{1} \times \mathrm{C}_{3}\right) \\
212.48\end{array}$ & $\begin{array}{c}\left(\mathrm{A}_{1} \times \mathrm{B}_{2} \times \mathrm{C}_{3}\right) \\
33.84\end{array}$ & $\begin{array}{c}\left(\mathrm{A}_{3} \times \mathrm{B}_{1} \times \mathrm{C}_{3}\right) \\
2.04\end{array}$ & $\begin{array}{c}\left(\mathrm{A}_{3} \times \mathrm{B}_{1} \times \mathrm{C}_{3}\right) \\
1.50\end{array}$ \\
\hline & \multicolumn{7}{|c|}{ Second season 2004} \\
\hline $\mathrm{A} \times \mathrm{B}$ & $\begin{array}{c}\left(\mathrm{A}_{1} \times \mathrm{B}_{1}\right) \\
18.77\end{array}$ & $\begin{array}{c}\left(\mathrm{A}_{1} \times \mathrm{B}_{1}\right) \\
3.93\end{array}$ & $\begin{array}{c}\left(\mathrm{A}_{1} \times \mathrm{B}_{1}\right) \\
271.81\end{array}$ & $\begin{array}{c}\left(\mathrm{A}_{1} \times \mathrm{B}_{1}\right) \\
221.03\end{array}$ & $\begin{array}{c}\left(\mathrm{A}_{1} \times \mathrm{B}_{2}\right) \\
35.60\end{array}$ & $\begin{array}{c}\left(\mathrm{A}_{3} \times \mathrm{B}_{1}\right) \\
2.08\end{array}$ & $\begin{array}{c}\left(\mathrm{A}_{3} \times \mathrm{B}_{1}\right) \\
1.57\end{array}$ \\
\hline $\mathrm{A} \times \mathrm{C}$ & $\begin{array}{c}\left(\mathrm{A}_{1} \times \mathrm{C}_{3}\right) \\
19.35\end{array}$ & $\begin{array}{c}\left(\mathrm{A}_{1} \times \mathrm{C}_{3}\right) \\
4.00\end{array}$ & $\begin{array}{c}\left(\mathrm{A}_{1} \times \mathrm{C}_{3}\right) \\
263.36\end{array}$ & $\begin{array}{c}\left(\mathrm{A}_{1} \times \mathrm{C}_{3}\right) \\
212.14\end{array}$ & $\begin{array}{c}\left(\mathrm{A}_{1} \times \mathrm{C}_{3}\right) \\
35.73\end{array}$ & $\begin{array}{c}\left(\mathrm{A}_{3} \times \mathrm{C}_{3}\right) \\
2.18\end{array}$ & $\begin{array}{c}\left(\mathrm{A}_{3} \times \mathrm{C}_{3}\right) \\
1.64\end{array}$ \\
\hline $\mathrm{B} \times \mathrm{C}$ & $\begin{array}{c}\left(\mathrm{B}_{1} \times \mathrm{C}_{3}\right) \\
18.22\end{array}$ & $\begin{array}{c}\text { NS. }\left(\mathrm{B}_{1} \times \mathrm{C}_{3}\right) \\
3.82\end{array}$ & $\begin{array}{c}\left(\mathrm{B}_{1} \times \mathrm{C}_{3}\right) \\
247.54\end{array}$ & $\begin{array}{c}\left(\mathrm{B}_{1} \times \mathrm{C}_{3}\right) \\
198.61\end{array}$ & $\begin{array}{c}\left(\mathrm{B}_{2} \times \mathrm{C}_{3}\right) \\
35.68\end{array}$ & $\begin{array}{c}\left(\mathrm{B}_{1} \times \mathrm{C}_{3}\right) \\
1.89\end{array}$ & $\begin{array}{c}\left(\mathrm{B}_{1} \times \mathrm{C}_{3}\right) \\
1.43\end{array}$ \\
\hline $\mathrm{A} \times \mathrm{B} \times \mathrm{C}$ & $\begin{array}{c}\left(\mathrm{A}_{1} \times \mathrm{B}_{1} \times \mathrm{C}_{3}\right) \\
19.65\end{array}$ & $\begin{array}{c}\left(\mathrm{A}_{1} \times \mathrm{B}_{1} \times \mathrm{C}_{3}\right) \\
4.03\end{array}$ & $\begin{array}{c}\left(\mathrm{A}_{1} \times \mathrm{B}_{1} \times \mathrm{C}_{3}\right) \\
283.12\end{array}$ & $\begin{array}{c}\left(\mathrm{A}_{1} \times \mathrm{B}_{1} \times \mathrm{C}_{3}\right) \\
231.11\end{array}$ & $\begin{array}{c}\left(\mathrm{A}_{1} \times \mathrm{B}_{2} \times \mathrm{C}_{3}\right) \\
36.59\end{array}$ & $\begin{array}{c}\left(\mathrm{A}_{3} \times \mathrm{B}_{1} \times \mathrm{C}_{3}\right) \\
2.19\end{array}$ & $\begin{array}{c}\left(\mathrm{A}_{3} \times \mathrm{B}_{1} \times \mathrm{C}_{3}\right) \\
1.67\end{array}$ \\
\hline
\end{tabular}

Land equivalent ratio (LER) and net return

Land equivalent ratio values in Table 9 indicated clearly that all values obtained under the treatment imposed exceeded the unit indicating yield advantage as compared when each component was grown alone. These results were true in both seasons. The only exception, was when maize density diminished to $33 \%$ (2:1) and peanut was shaded by maize spaced $35 \mathrm{~cm}$ apart leaving one plant/hill and the plot received lowest nitrogen fertilizer dose $(60 \mathrm{~kg} \mathrm{~N} / \mathrm{fed})$ in the first season only where LER was less than the unit with no yield advantage being achieved. Results of the interaction indicate that LER obtained from (1:1) pattern were generally superior to $(2: 1)$ or $(1: 2)$ pattern either. Moreover, LER values of (1:2) pattern were always higher than in $(2: 1)$ pattern under same respective nitrogen fertilizer dose. (2:1) pattern recorded lowest values. LER values also increased with increasing the nitrogen fertilizer level. Within orientation patterns of the shade crop LER of $70 \mathrm{~cm}$ spaced plants and two plants/hill were left were relatively higher than those spaced at $35 \mathrm{~cm}$ spaced and one plant/hill, due to increasing light efficiency and decreasing the shading effect on the understory crop.

Egypt. J. Agron. 34, No. 1 (2012) 
TABLE 9. Effect of intercropping patterns, orientation of maize plants and nitrogen fertilizer levels on land equivalent ratio (LER) and net return in 2003 and 2004 seasons.

\begin{tabular}{|c|c|c|c|c|c|c|}
\hline \multicolumn{3}{|c|}{$\begin{array}{ll}\text { Treatments } & \text { Traits } \\
\end{array}$} & \multicolumn{2}{|c|}{ First season 2003} & \multicolumn{2}{|c|}{ Second season 2004} \\
\hline $\begin{array}{l}\text { Inter. } \\
\text { patterns }\end{array}$ & $\begin{array}{c}\text { Orient. of } \\
\text { maize } \\
\text { plants }\end{array}$ & $\begin{array}{c}\mathrm{N} \\
\text { levels } \\
\mathrm{kg} / \mathrm{fed}\end{array}$ & LER & $\begin{array}{c}\text { Net } \\
\text { return } \\
\text { (L.E.) }\end{array}$ & LER & $\begin{array}{c}\text { Net } \\
\text { return } \\
\text { (L.E.) }\end{array}$ \\
\hline \multirow{6}{*}{ 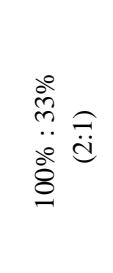 } & \multirow{3}{*}{$\begin{array}{c}35 \mathrm{~cm} \text { apart } \\
\text { (one } \\
\text { plant/hill) }\end{array}$} & 60 & 0.99 & 908.99 & 1.03 & 1372.82 \\
\hline & & 90 & 1.10 & 1141.89 & 1.13 & 1588.53 \\
\hline & & 120 & 1.17 & 1203.91 & 1.16 & 1590.37 \\
\hline & \multirow{3}{*}{$\begin{array}{c}70 \mathrm{~cm} \text { apart } \\
\text { (two } \\
\text { plants/hill) }\end{array}$} & 60 & 1.16 & 1444.48 & 1.18 & 1730.29 \\
\hline & & 90 & 1.28 & 1692.76 & 1.27 & 1904.76 \\
\hline & & 120 & 1.34 & 1754.21 & 1.30 & 1955.26 \\
\hline \multirow{6}{*}{ 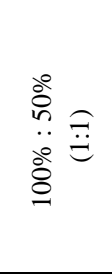 } & \multirow{3}{*}{$\begin{array}{c}35 \mathrm{~cm} \text { apart } \\
\text { (one } \\
\text { plant/hill) }\end{array}$} & 60 & 1.07 & 990.86 & 1.11 & 1592.44 \\
\hline & & 90 & 1.19 & 1212.29 & 1.21 & 1811.92 \\
\hline & & 120 & 1.26 & 1284.14 & 1.26 & 1868.52 \\
\hline & \multirow{3}{*}{$\begin{array}{c}70 \mathrm{~cm} \text { apart } \\
\text { (two } \\
\text { plants/hill) }\end{array}$} & 60 & 1.23 & 1481.80 & 1.25 & 1912.24 \\
\hline & & 90 & 1.37 & 1764.14 & 1.36 & 2149.69 \\
\hline & & 120 & 1.44 & 1851.71 & 1.41 & 2214.95 \\
\hline \multirow{6}{*}{ 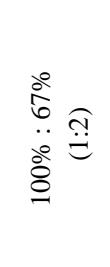 } & \multirow{3}{*}{$\begin{array}{c}35 \mathrm{~cm} \text { apart } \\
\text { (one } \\
\text { plant/hill) }\end{array}$} & 60 & 1.06 & 798.88 & 1.08 & 1462.11 \\
\hline & & 90 & 1.19 & 1034.20 & 1.19 & 1690.35 \\
\hline & & 120 & 1.25 & 1087.48 & 1.22 & 1729.83 \\
\hline & \multirow{3}{*}{$\begin{array}{c}70 \mathrm{~cm} \text { apart } \\
\text { (two } \\
\text { plants/hill) }\end{array}$} & 60 & 1.24 & 1309.16 & 1.23 & 1849.49 \\
\hline & & 90 & 1.37 & 1568.55 & 1.35 & 2131.93 \\
\hline & & 120 & 1.43 & 1648.21 & 1.40 & 2211.19 \\
\hline
\end{tabular}

- Pure stands were: $1.36,1.17$ ton pods/fed and 1.27, 1.11 ton straw/fed for peanut and 2.97, 3.29 ton grains/fed and 2.37, 2.55 ton straw/fed for maize for 2003 and 2004 seasons, respectively.

- Ton price in 2003 season: (Peanut pods $=2133.33$ L.E., foliage $=40.00$ L.E.) \& (Maize grains $=692.86$ L.E., straw $=76.00$ L.E. $)$.

- Ton price in 2004 season: (Peanut pods $=2253.33$ L.E., foliage $=40.00$ L.E.) \& (Maize grains $=1035.71$ L.E., straw $=76.00$ L.E. $)$.

Maximum LER was obtained when the intercrop received $120 \mathrm{~kg} \mathrm{~N} / \mathrm{fed}$ and peanut plants were grown under the $50 \%$ of maize plants $\left(2.4\right.$ plants $\left./ \mathrm{m}^{2}\right)$ orientated at $70 \mathrm{~cm}$ apart and two plants/hill were left in (1:1) pattern.

Yield advantage in the intercrop as compared with sole cropping were also supported by Calavan \& Weil (1988) who found that peanut-maize intercrop resulted in land equivalent rate ranging from 1.28 to 1.49 and Eliseu \& Freire (1992) who also found that peanut-maize intercrop gave yield advantage estimated to $1.20-1.99$, particularly in peanut-maize $(3: 1)$. 
Results on net return presented in Table 9 also indicated that the treatment effect had apparent impose on net return with increases in nitrogen fertilizer level from 60 to $120 \mathrm{~kg} \mathrm{~N} / \mathrm{fed}$ under all the intercrop patterns.

The results also evidenced that within any intercrop, net return (on average basis) when peanut plants were grown at $70 \mathrm{~cm}$ spaced maize plant with two plants/hill were higher than those orientated at $35 \mathrm{~cm}$ spaced maize plant leaving one plant/hill. Maximum net return was recorded when the intercrop plots received $120 \mathrm{~kg} \mathrm{~N} / \mathrm{fed}$ and peanut plants were grown under $50 \%$ of full stand of maize plants orientated at $70 \mathrm{~cm}$ apart with two plants/hill. Whereas, when the intercrop plot received $120 \mathrm{~kg} \mathrm{~N} /$ fed and peanut was grown under $67 \%$ of full stand of maize plants orientated at $70 \mathrm{~cm}$ apart with two plants/hill had the second net return indicating that increasing the shade crop density to maximum, $67 \%\left(3.2\right.$ plants $\left./ \mathrm{m}^{2}\right)$ had no beneficial effect whether on production per unit of land (measured in LER) or any more economical value (measured in net return).

However, it could be concluded that differences were only appreciable between $(1: 1)$ and $(1: 2)$ or $(2: 1)$ patterns which stimulate the need to more plant density of maize to improve the net return of the intercrop particularly if the price unit of the shade crop increased, i.e., increasing the shade crop up to $67 \%$ or decreasing it to $33 \%$ of its full stand density is mainly dependant on the price unit of the shade crop.

\section{References}

Abd El-Motaleb, H. M. and Yousef, M. S. H. (1998) Intercropping maize with two varieties of peanut under two levels of nitrogen fertilizer. Proc. $8^{\text {th }}$ Conf. Agron., Suez Canal Univ., Ismaillia, Egypt, 28-29 Nov. pp.544-552.

Calavan, K.M. and Weil, R.R. (1988) Peanut-corn intercrop performance as affected by within-row corn spacing at a constant row spacing. Agron. J. 80, 635-642.

Duncan, D. B. (1955) Multiple range and multiple "F. test". Biometrics, 11, 1-42.

Economic Affairs Sector EAS (2004) Summer and Nile crops 2003. Bull. Agricultural Statistics, Ministry of Agriculture and Land Reclamation, Egypt, 2, 1-351. (In Arabic).

Economic Affairs Sector EAS (2005) Summer and Nile crops 2004. Bull. Agricultural Statistics, Ministry of Agriculture and Land Reclamation, Egypt. 2, 1-380. (In Arabic).

El-Bana, A. Y. and Gomaa, M.A. (2000) Effect of N and $\mathrm{K}$ fertilization on maize grown in different populations under newly reclaimed sandy soil. Zagazig J. Agric. Res. 27 (5), 1179-1196.

El-Douby, K.A., Ali, E.A. and Toaima, S.E.A. (2001) Effect of nitrogen fertilizer, defoliation and plant density on maize grain yield. Egypt. J. Agric. Res. 79 (3), 965982.

Egypt. J. Agron. 34, No. 1 (2012) 
El-Hosary, A.A. and Salwau, M.I.M. (1989) Effect of N levels and plant density on yield and some agronomic characters in maize (Zea mays L.) Ann. Agric. Sci. Moshtohor, 27 (2), 783-795.

Eliseu, J. M. and Freire, M. J. (1992) Effect of plant density and sowing pattern on the yield of a groundnut/maize intercrop. Proc. $5^{\text {th }}$ Regional Groundnut Workshop for Southern Africa, 9-12 March, Lilongwe, Malawi. pp.121-123.

Hardy, R.W.F. and Havelka, U.D. (1973) Photosynthate as a major factor limiting nitrogen fixation by field grown legumes with emphasis on soybeans. In: "Symbitic Nitrogen Fixation in Plants". P.S. Nutman (Ed.) pp. 421-439. IBP7. Cambridge Univ. Press, London.

Hussein, Samira M.A. (2005) Optimizing utilization of nitrogen fertilizer under some intercropping systems of groundnut and maize in sandy soil. J. Agric. Sci., Mansoura Univ. 30 (9), 4979-4989.

Hussein, Samira M.A., Shams, S.A.A. and El-Melegy, A.M. (2002) Effect of some intercropping patterns and foliar application with nutrients mixture on yield of maize and peanut. Ann. Agric. Sci. Moshtohor, 40 (3), 1427-1447.

Ibrahim, A.A. and Abd El-Maksoud, M.F. (2001) Leaf defoliation and hill spacing effects on maize productivity. Zagazig J. Agric. Res. 28 (2), 261-274.

Lanier, J. E., Jordan, D. L., Spears, J. F., Wells, R. and Johnson, P. D. (2005) Peanut response to inoculation and nitrogen fertilizer. Agron. J. 97, 79-84.

Liphadzi, M. S., Thomas, R.M. and Hammes, P.S. (1997) Competition between intercropped maize (Zea mays L.) and groundnut (Arachis hypogaea L.). App. Plant Sci. 11 (2), 31-34.

Lucas, E.O. (1986) The effect of density and nitrogen fertilizer on the growth and yield of maize (Zea mays L.) in Nigeria. J. Agric. Sci. Comb. 107, 573-578.

Mandimba, G. R., Galandzou, C. and Guenguie, N. (1993) Effect of plant population densities on the growth of Zea mays L. and Arachis hypogaea L. in intercropping systems. Biol. Agric. \& Hort. 10 (2), 141-154.

Metwally, A.A., Mahamed, G.O., Shereif, M. N. and Awad, M. M. (2005) Yield and land equivalent ratio of intercropped corn and groundnut. Proc. $11^{\text {th }}$ Conf. Agron., Assiut Univ., 15-16 Nov., pp. 201-211.

MSTAT-C (1988) A micro-computer program for the design, management, and analysis of agronomic research experiments. Michigan State Univ., East Lansing, MI.

Patra, B. and Poi, S. C. (1998) Influence of intercropping on the nodulation in legumes. Environ. Ecol. 16 (2), 418-423.

Senaratne, R. and Ratnasinghe, D. S. (1993) N supply by groundnuts to maize in a maize plus groundnut intercropping system, as affected by the genotype. Biol. Fert. Soils, 15 (3), 215-219. 
Shams, A.S.A.A. (2002) Effect of biological and mineral fertilizer on growth and yield of maize intercropped with soybean. M.Sc. Thesis. Fac. of Agric. Moshtohor Zagazig Univ. (Benha Branch).

Sherif, Sahar A., Zohry, A.A. and Ibrahim, Sahar, T. (2005) Effect of planting dates and densities of maize intercropped with groundnut on growth, yield and yield components of both crops. Arab Univ. J. Agric. Sci., Ain Shams Univ. 13 (3), 771-791.

Willey, R.W. (1979) Intercropping. Its importance and research needs. Part 1: Competition and yield advantages, Field Crop Abstr. 32, 1-10.

(Received 8 / 3 / 2012; accepted $15 / 7 / 2012)$

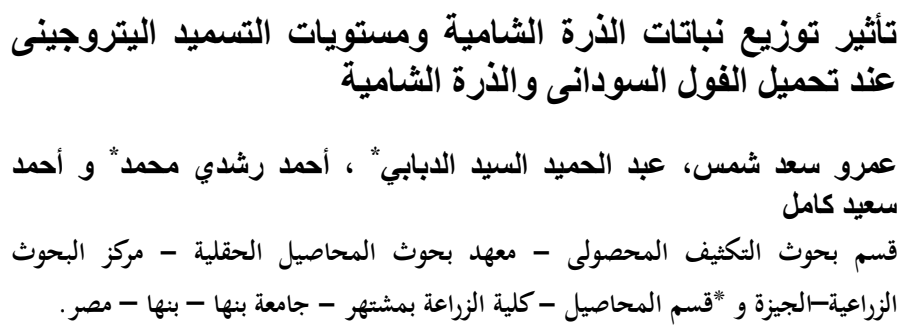

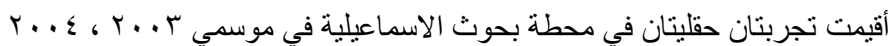

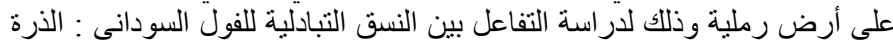

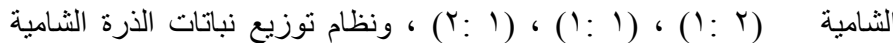

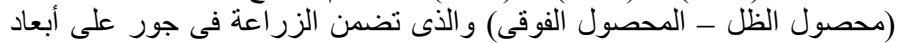

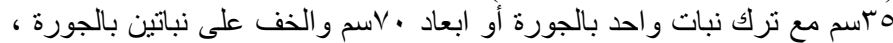

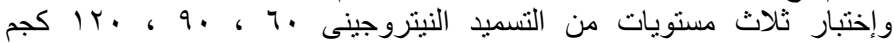

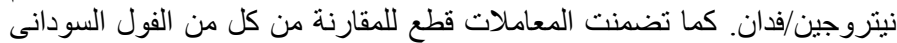

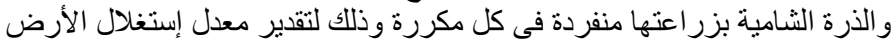

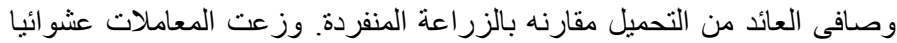

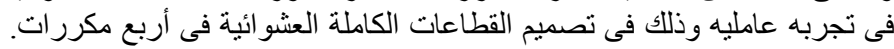

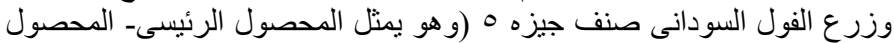

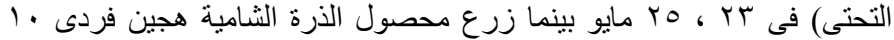

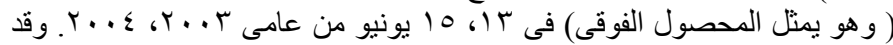

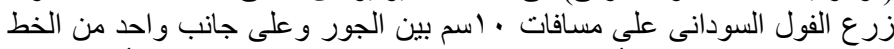

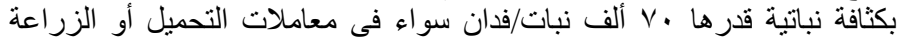

$$
\text { المنفردة. }
$$

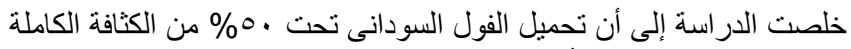

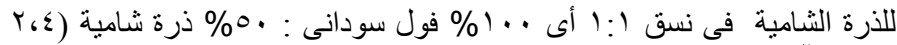

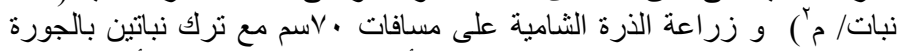

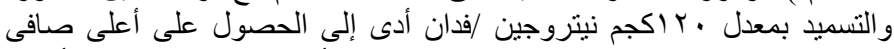

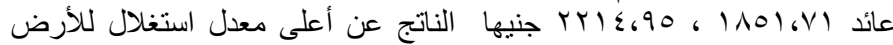

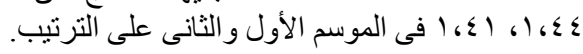

Egypt. J. Agron. 34, No. 1 (2012) 
Egypt. J. Agron. 34, No. 1 (2012) 